Sierra rivers is greater in the north than in the south. In addition the San Joaquin Valley and Southern California require the power that can be developed in the Sierras southeast of the Bay Districts.

The suggestion has been made that there would be important advantages in having a high capacity trunk line running through the Sacramento and San Joaquin valleys to which all the power companies could be connected and through which power could be exchanged. To provide the necessary capacity for this purpose, such a trunk line would have to be operated at high voltage and to safeguard service would have to be in duplicate with sectionalizing stations at intervals. The existing lines of the power companies do not fulfill the requirements of such a trunk even in part.

The engineering problems which would be encountered in the construction and operation of such a trunk are numerous and difficulte Let us assume that such a trunk would consist of two $150-\mathrm{kv}$., 60-cycle circuits from Kennet to Bakersfield, a distance of 420 miles. The charging current at full voltage would require $50,000 \mathrm{kv}-\mathrm{a}$. per circuit or $100,000 \mathrm{kv}$-a. for both circuits, and this is much more than the capacity of any one hydroelectric plant in California.

It seems probable that further interconnections will be worked out more nearly along the lines that have been followed in the past. This has usually involved the construction of comparatively short and inexpensive interconnections in specific cases where an exchange of power was economically desirable.

\title{
CALIFORNIA-OREGON POWER CO. AND NORTHERN CALIFORNIA POWER CO.
}

BY WILLIAM M. SHEPARD

$\mathrm{T}$ HE proposed interconnection of the California Oregon Power Company with the other power companies of California would be made through the system of the Northern California Power Company to the lines of the Pacific Gas and Electric Company near Colusa. The Northern California Power Company has already a connection with the system of the Pacific Gas and Electric Company at Chico, and delivers from 8000 to $10,000 \mathrm{kw}$. which is the limit of the available line capacity of both companies at this point.

Delivery near Colusa would be considerably nearer the center of load of the Pacific Gas and Electric Company, being 
about 50 miles further south and west by way of transmission lines than Chico.

The connection between the California-Oregon Power Company and the Northern California Power Company will be made at Kennet, the California-Oregon Power Company extending its lines from Castella south a distance of about 32 miles and reinforcing its lines from Castella north to Copco, a distance of 63 miles, raising the voltage on this line from 60,000 volts to 66,000 volts and increasing the copper in the line from No. 2 to No. 00 .

The California-Oregon Power Company will then deliver at Kennet approximately $8600 \mathrm{kw}$. which will release about $9100 \mathrm{kw}$. at the power houses of the Northern California Power Company, the Northern California Power Company transmitting about 35 miles north to Kennet at present and the load in this vicinity being between $8500 \mathrm{kw}$. and $9000 \mathrm{kw}$. with a line loss of approximately 6.5 per cent.

In order to transmit this power released at the plants of the Northern California Power Company south, it is proposed to increase the capacity of the $66-\mathrm{kv}$. line from Coleman to Willows Junction, a distance of 55 miles, and from Willows Junction to Hamilton, a distance of 10 miles, from No. 1 to No. 000 copper. From Willows Junction to the connection point with the Pacific Gas and Electric Company near Colusa there are two $66-\mathrm{kv}$. lines, one 48 miles of No. 4 and one 43 miles, 10 miles to be reinforced to No 000 to Hamilton, the balance being No 1 .

The present lines have in the summer a combined load of about $4000 \mathrm{kw}$. This falls off in about 1000 to $1200 \mathrm{kw}$. in winter due to the irrigation load.

This reinforcement of line capacity would allow the delivery of the present summer load plus $8000 \mathrm{kw}$. near Colusa. The total line loss for $12,000 \mathrm{kw}$. delivered being about $1350 \mathrm{kw}$. The line loss over the present lines with the summer load is approximately $230 \mathrm{kw}$. making a net additional loss chargeable to the $8000-\mathrm{kw}$. delivered at Colusa of about $1120 \mathrm{kw}$. In other words the $9120 \mathrm{kw}$. released at the power houses of the Northern California Power Company by the delivery from the California-Oregon Power Company at Kennet of $8620 \mathrm{kw}$. will make available at Colusa $8000 \mathrm{kw}$.

The loss on the California-Oregon Power Company lines from Copco to Kennet will be about $880 \mathrm{kw}$. This means that 
PLATE LXXVIII.

A I. E. E.

VOL. XXXVII, NO. 12

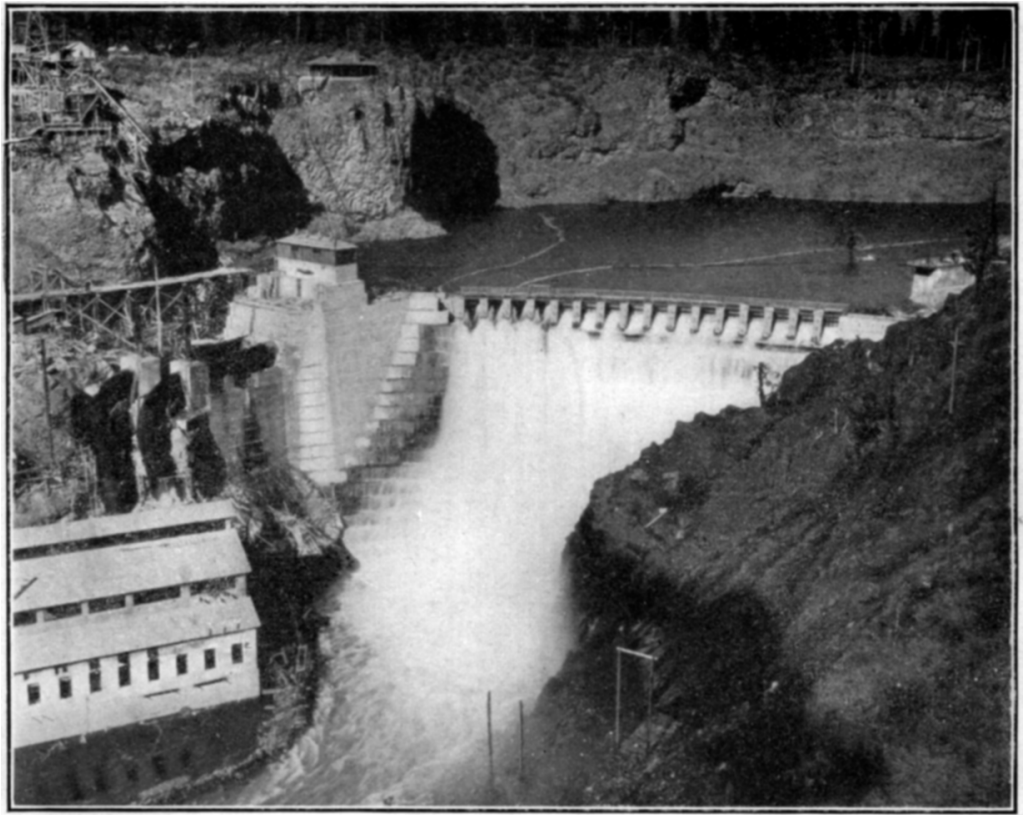

Fig. 1-Power House and Dam-Copco Power Development

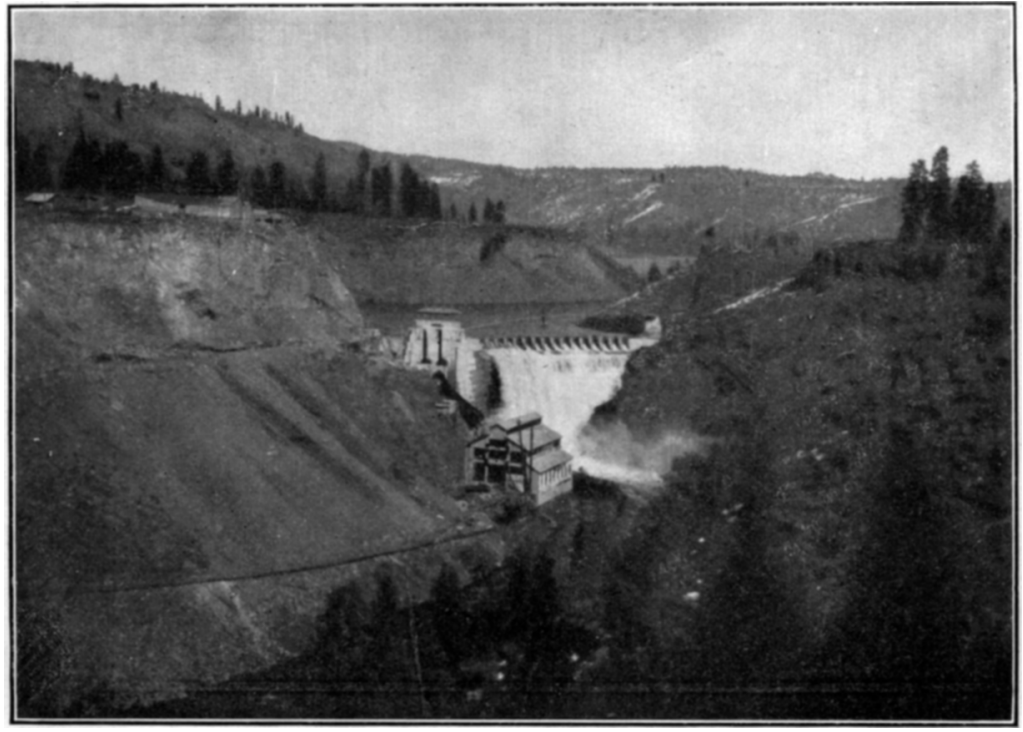

[SHEPARD]

Fig. 2-Copco Power Development California-Oregon Power Co. Klamath River, California 

$9500 \mathrm{kw}$. at Copco will deliver through the means just described $9000 \mathrm{kw}$. near Colusa into the Pacific Gas and Electric system the net transmission loss being about 16 per cent of the generated power.

This interconnection will make available a block of power 230 miles distant largely through the medium of existing facilities and with reasonable losses. The maximum actual distance of transmission is about 100 miles, from Coleman to the delivery point near Colusa.

It is also possible to deliver during the winter months when the irrigation load of the Northern California Power Company is off, an additional block of from $3000 \mathrm{kw}$. to $4000 \mathrm{kw}$. over these same lines. This additional power can be delivered during a period of seven months from October 1st to May 1st and could be used as needed by the Pacific Gas and Electric Company.

The Northern California Power Company has considerable excess generating capacity over its available water supply and for this reason is in an excellent position to control the voltage at Kennet, the power factor of the load taken by the CaliforniaOregon Power Company and therefore the capacity of its lines into Kennet. As a matter of fact, $1100 \mathrm{kw}$. of generating capacity in the Northern California Power houses will give the same result, as a $2800-\mathrm{kv}$-a. synchronous condenser at Kennet and will allow the California-Oregon Power Company to deliver at above 95 per cent power factor.

The power factor of the load moving south from the Northern California Power Company's plants will also be high on account of the large amount of $66-\mathrm{kv}$. transmission line, there being about 185 miles of this line, the charging current of which will be available for raising the power factor of this load. It is assumed that the $8000 \mathrm{kw}$. will be delivered at Colusa at 85 per cent power factor, the local loads at 80 per cent power factor. On this basis the power factor at the plants of the Northern California Power Company could be in the neighborhood of 95 per cent.

The power from the California-Oregon Power Company system is made available by the recent installation of the first unit of the Copco power development on the Klamath River, near the Oregon Line.

The ultimate development at this site will consist of two units, each consisting of a $12,500-\mathrm{kv}-\mathrm{a}$. generator driven by 
an 18,600-h.p. double Francis turbine designed for operation under 125 feet head. Water is supplied to the present turbine through two steel pipes 10 feet in diameter, and 200 feet long.

The pipes are connected to the reservoir through a gate house structure of reinforced concrete, forming the west abutment for the top 40 feet of the dam. The center line of the pipes being some 27 feet below high water level in the reservoir, thus making available the upper 12 feet or approximately 9000 acre-feet of water for pondage. This represents a reserve of $750,000 \mathrm{kw}-\mathrm{hr}$.

With the complete development and control of the river, $20,000 \mathrm{kw}$. will be obtainable at 75 per cent load factor, or 25,000 $\mathrm{kw}$. at 60 per cent load factor throughout the year.

\section{FUEL CONSERVATION BY INTERCONNECTIONS WITH THE SYSTEM OF THE SIERRA \& SAN FRANCISCO POWER COMPANY}

BY J. E. WOODBRIDGE

$\mathrm{N}$ so far as it is of interest from the standpoint of interconnection, the system of the Sierra and San Francisco Power Company consists essentially of the following elements:

1. A hydroelectric plant in the Stanislaus canyon, with four $8500-\mathrm{kw}$. units operating under a head of 1500 feet, and a forebay having a capacity equivalent to approximately 300,000 kw-hr.

2. A two-circuit steel tower transmission line, operated nominally at 104,000 volts, with a length of 135 miles to San Francisco, each circuit of No. 00 wire having a capacity usually considered as $20,000 \mathrm{kw}$.

3. A steam power plant in San Francisco, containing three 9000-kw. generators.

4. A load of from 550,000 to $600,000 \mathrm{kw}$-hr. per day, with a peak of approximately $40,000 \mathrm{kw}$., a large portion of this load being street car service in San Francisco supplied through synchronous motor-generator sets.

In so far as the consumption of fuel oil is concerned, the following facts are of primary importance:

a. The system has little or no hydroelectric generated energy to spare, since the average daily load is about equal to the flume capacity.

b. Some fuel oil must be burned in the Company's San Francisco steam standby station even during flood water periods, 